\title{
Communication
}

\section{Database on Microbial Thermal Death: Its Construction Design Based on Data from Published Papers and from Experiments Performed under Defined Conditions ${ }^{\dagger}$}

\author{
ICHIRO NAKAMURA ${ }^{1,2}$, TAKASHI YOKOHARA ${ }^{1,3}$ \\ AND TETSUAKI TSUCHIDO', 4, 5*

\begin{abstract}
'TriBioX Laboratories, 1-125 Tamaoka-cho, Takano, Sakyo-ku, Kyoto 606-8106, Research Center, Kansai University, Yamate-cho, Suita 564-8680, Japan
\end{abstract} \\ ${ }^{2}$ Department of Life Science, Chukyo Junior College, Toki-cho, Mizunami 509-6101, \\ ${ }^{3}$ Faculty of Humanities, Soai University, Nanko-naka, Suminoe-ku, Osaka 559-0033, \\ and ${ }^{4}$ Department of Biotechnology, Faculty of Engineering and ${ }^{5} \mathrm{High}$-Technology
}

Received 26 August 1999/Accepted 27 September 1999

\begin{abstract}
To build a database on the thermal death of microorganisms, we designed a formulated card system consisting of more than 60 items. Those items are displayed on a card on the monitor screen of a personal computer and most of the corresponding parameters for each item are selectable by clicking. Data from research papers published so far and from experiments performed under defined environmental, microbiological, and operational conditions have been collected for the database.
\end{abstract}

It has often been stressed that so-called predictive microbiology should be introduced for guaranteeing the microbiological safety of foods and studies on this novel approach have recently appeared (Buchanan and Whiting 1996; Fujikawa and Itoh, 1997; Yano, 1998). A substantial amount of data have been collected on the growth and death of various bacteria as influenced by different environmental factors such as temperature, $\mathrm{pH}$, and water activity (e.g., the concentration of sodium chloride). Based upon those data, the database has been built, and further, with the aid of predictive microbiology, two practical computer software programs have been developed for the predictions of food spoilage and preventive effects of a process: "Food Micromodel" in U. K. and "Pathogen Modeling Program" in U. S. A., (McClure et al., 1994; Roberts, 1997; Tsuchido, 1998; Whiting, 1997).

\footnotetext{
* Corresponding author. Department of Biotechnology, Faculty of Engineering, Kansai University, Yamate-cho, Suita 564-8680, Japan. Tel : +81-6-6368-0880, Fax : + 81-6-6388-8609.

+ This article is dedicated to the late Dr. Toshiharu Kawabata, the past-president of the Japan Society for Research of Food Protection.
}

However, the species of bacteria introduced into those database programs are limited to mostly pathogenic ones and little data on spoilage bacteria have been collected yet. Also, the software programs for microbial thermal death, which have been developed so far, do not seem to provide users with sufficiently reliable prediction, compared to those for bacterial growth and spoilage. One of the reasons for such a low reliability in the prediction of thermal death may be the insufficient definition of experimental conditions for the collection of data. In fact, numerous factors have been known to affect the cellular resistance to heat, including factors not only during but also before and after the heat treatment, but also those affecting before and after heat treatment, in contrast to the number of factors involved in microbial growth and spoilage (Tsuchido, 1997). It should be examined which factors are most critical and how those factors affect the heat resistance of a microorganism. Also, it may be desirable that all of the experimental conditions are strictly defined for the determination of heat resistance of a microorganism.

We have previously reported that the thermal history of vegetative cells, such as preincubation 
temperature, postincubation temperature, and rising temperature rate, profoundly affects the heat resistance of cells (Katsui et al., 1981 and 1982; Tsuchido et al., 1974 and 1982). However, for most of researchers, not much attention seems to have been paid to these aspects in the determination of heat resistance of bacterial cells. Therefore, at least part of the often seen substantial differences between the predicted data and observed data on heat resistance may be ascribed to the effects of the thermal history of the cells.

Considering these situations, we started in 1997 to build a thermal death database for microorganisms in two ways. One has been to collect data published so far in some selected journals and the other has been to obtain data from experiments in which various conditions are strictly defined and well controlled.

In the first approach, we have been collecting thermal death data from papers published in several related journals distributed worldwide or journals wellknown in Japan, which are listed in Table 1. We are further planning to increase the number of journals to scrutinize. The data from those published papers have been collected from the year 1999 back to the past. Through this approach, it is expected that some suggestive information on reliable predictions of the thermal death of microorganisms could be obtained for practical use.

As for the second approach, we have also been collecting data from experiments performed under defined conditions involving environmental, microbiological, and operational factors. A strain of Escherichia coli, OW6 (Miyake et al., 1993), was chosen as an objective organism and data of its thermal death at different temperatures, different $\mathrm{pHs}$, and different concentrations of sodium chloride have been obtained under strictly defined conditions, which are described in Table 2. To obtain survival data, we have been using the growth-delay analysis method, which has been proposed by Takano and Tsuchido (1982), instead of the conventional colony count method, because of its easiness to use, efficiency and reproducibility of measurement.

The collected data from both approaches have been incorporated into a database system constructed with a database software, FileMaker Pro 4.1 v1 (FileMaker Inc.) using a personal computer (Gateway 2000, P5-66 or Power Macintosh 7600/ 200). The number of items selected here amounts to as many as 60, including the kind of microorganism, cell form (vegetative cell or spore), conditions of heat activation for spores, the presence of oxygen, redox potential, water activity, kind and concentration of solute dissolved in the heating menstruum, heating apparatus or instrument, $D$ value, $Z$ value, predicted values of $D_{60^{\circ} \mathrm{C}}$ and $D_{120^{\circ} \mathrm{C}}$, pattern of survival curve (the appearance of shoulder and/or tailing), method and conditions for the viability assay, in addition to the items of experimental conditions shown in Table 2. All these items are displayed on a monitor screen and most of corresponding parameters for each item can be selected by clicking a pop-up button on the dis-

TABLE 1 . List of journals used as sources of data for the building of the database on microbial thermal death as of the year 1999 .

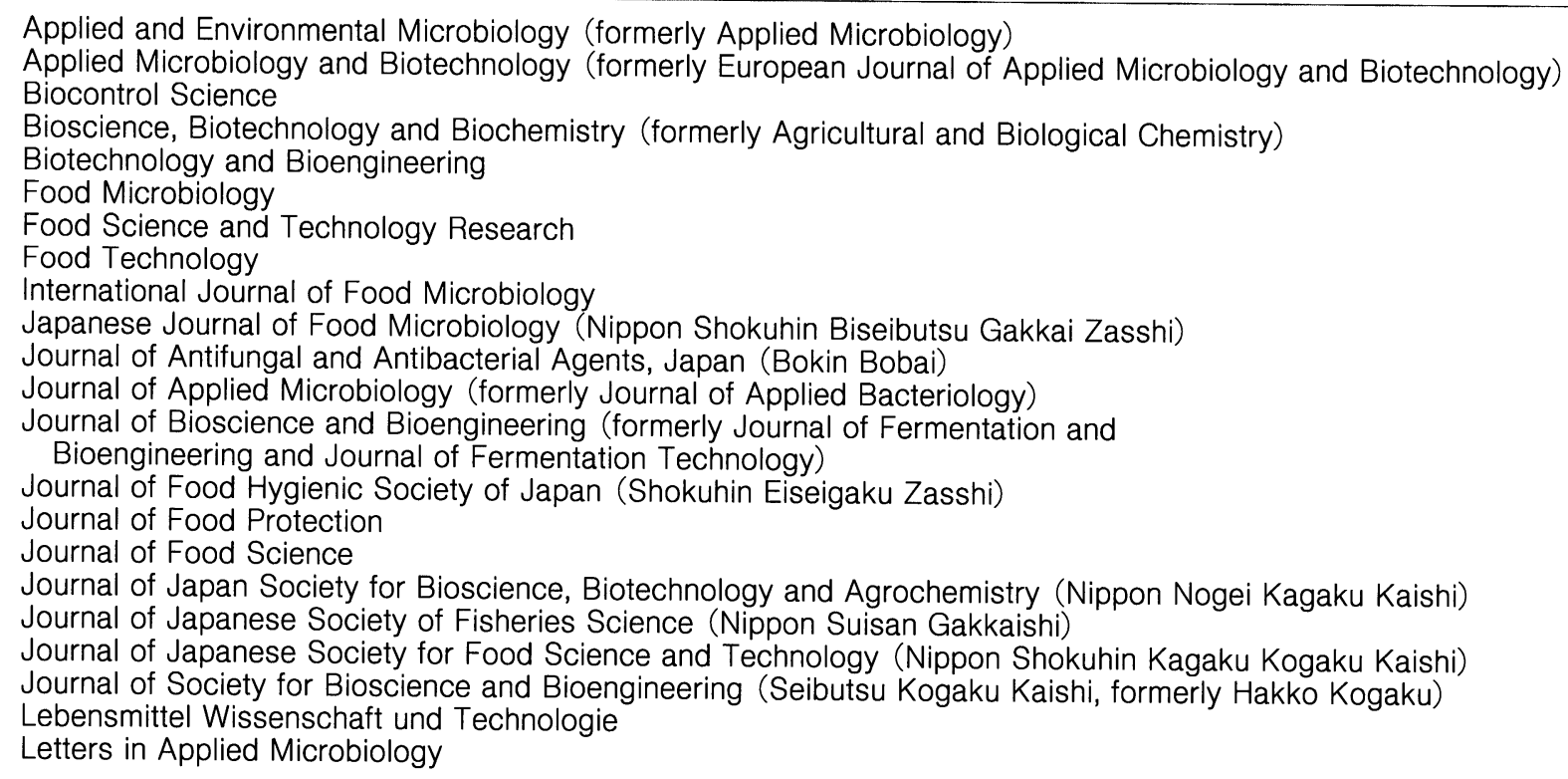


TABLE 2. Basic experimental conditions for obtaining thermal death data of $E$. coli.

\begin{tabular}{|c|c|}
\hline Factor & Conditions \\
\hline \multicolumn{2}{|l|}{ Before heat treatment } \\
\hline Temperature & $37^{\circ} \mathrm{C}$ \\
\hline $\mathrm{pH}$ & 7.0 \\
\hline Growth medium & EM9 broth ${ }^{a}, 20 \mathrm{ml}$ \\
\hline Time & $\begin{array}{l}16 \mathrm{~h} \text { (precultivation) and then } 2.5 \mathrm{~h} \text { after } \\
\text { inoculation ( } 2 \% \text { as an inoculum size) }\end{array}$ \\
\hline Growth phase & Logarithmic phase (an $\mathrm{OD}_{650}$ of 0.3 ) \\
\hline Shaking speed & $120 \mathrm{rev} / \mathrm{min}$ \\
\hline \multicolumn{2}{|l|}{ For harvesting and washing } \\
\hline Centrifugation conditions & $5,000 \times g, 5 \min , 4^{\circ} \mathrm{C}$ \\
\hline Washing & $\begin{array}{l}\text { Twice with } 50 \mathrm{mM} \text { potassium phosphate } \\
\text { buffer ( } \mathrm{pH} 7.0)\end{array}$ \\
\hline Resuspending conditions & $0^{\circ} \mathrm{C}, 3 \mathrm{ml}$ as a final volume \\
\hline Final cell density & ca. $10^{9}$ cells $/ \mathrm{ml}$ \\
\hline \multicolumn{2}{|l|}{ For preincubation } \\
\hline Temperature, time and others & $0^{\circ} \mathrm{C}, 60 \mathrm{~min}$, with shaking \\
\hline \multicolumn{2}{|l|}{ During heat treatment } \\
\hline \multicolumn{2}{|l|}{ For starting heat treatment } \\
\hline Rising temperature process & 100-fold dilution method \\
\hline \multicolumn{2}{|l|}{ For isothermal heating } \\
\hline Temperature & $48-56^{\circ} \mathrm{C}$ \\
\hline $\mathrm{pH}$ & $5.5-8.0$ \\
\hline Menstruum & $50 \mathrm{mM}$ potassium phosphate buffer \\
\hline Initial cell density & $10^{7} \mathrm{cells} / \mathrm{ml}$ \\
\hline Shaking speed & $120 \mathrm{rev} / \mathrm{min}$ \\
\hline Vessel & $100-\mathrm{ml} \mathrm{flask}$ \\
\hline Heating apparatus & water-bath incubator \\
\hline \multicolumn{2}{|l|}{ For ending heat treatment } \\
\hline Falling temperature process & $\begin{array}{l}10 \text {-fold dilution method; cooled to } 37^{\circ} \mathrm{C} \text {, } \\
\text { incubated at this temperature for } 1 \mathrm{~min} \text {, } \\
\text { and then cooled gradually to } 0^{\circ} \mathrm{C}\end{array}$ \\
\hline \multicolumn{2}{|l|}{ After heat treatment } \\
\hline \multicolumn{2}{|l|}{ For postincubation } \\
\hline Temperature and others & $0^{\circ} \mathrm{C}$, within $1 \mathrm{~h}$, with shaking \\
\hline \multicolumn{2}{|l|}{$\begin{array}{l}\text { For viability measurement by the } \\
\text { growth delay method }\end{array}$} \\
\hline Temperature & $37^{\circ} \mathrm{C}$ \\
\hline $\mathrm{pH}$ & 7.0 \\
\hline Assay medium & EM9 broth \\
\hline Inoculation & $10 \%$ \\
\hline
\end{tabular}

play. Also, the gram-stain type and optimal growth temperature of bacterium, and the $\mathrm{pH}$ of cultivation medium can be automatically recorded from files related to the system.

As described above, the thermal death behavior of the organism is influenced by a variety of factors, some of which are mentioned in this study (Tsuchido, 1997). The set of parameters adopted in this study is only one example among numerous combinations of a variety of factors. In order to build a substantial database which can be available as soon as possible, it is not the best way, or rather impossible, to obtain data for all cases of combinations of experimental conditions. It is useful, therefore, to standardize kinetic formulations expressing dependencies on those factors and to characterize the thermal death behavior, as one of the possible approaches. The principles of such a standardized method will be described elsewhere.

Once such a database is built up, it should be extremely useful not only for the estimation of the heat resistance of a microorganism under untested novel conditions, but also for the practical predictions regarding the thermal death of target microorganisms, through mathematical modeling, in food pasteurization and sterilization processes. The first results of our on-going work on the construction of a database on microbial thermal death will be published shortly. 


\section{ACKNOWLEDGMENTS}

We thank the late Dr. Toshiharu Kawabata, the pastpresident of the Japan Society for Research of Food Protection, for his recommendation of and encouragement in performing this study.

This study was supported by the grant of the Japan Food Industry Center (JAFIC).

\section{REFERENCES}

Buchanan, R. L., and Whiting, R. C. (1996) Risk assessment and predictive microbiology. J. Food Prot., Suppl., 31-36.

Fujikawa, H., and Itoh, T. (1997) Present situations and advantages of predictive microbiology (in Japanese). In Application of Predictive Microbiology to Food (ed., Yano, N., Kobayashi, T., and Fujikawa, H.), pp. 28-41, Science Forum, Tokyo.

Katsui, N., Tsuchido, T., Takano, M., and Shibasaki, I. (1981) Effect of preincubation temperature on the heat resistance of Escherichia coli having different fatty acid compositions. J. Gen. Microbiol., 122, 357-361.

Katsui, N., Tsuchido, T., Takano, M., and Shibasaki, I. (1982) Viability of heat-stressed cells of microorganisms as influenced by preincubation and postincubation temperatures. J. Appl. Bacteriol., 53, 103-108.

McClure, P. J., Blackvurn, C. De W., Cole, M. B., Curtis, P. S., Jones, J. E., Legan, J. D., Ogden, I. D., Peck, M. W., Roberts, T. A., Sutherland, J. P., and Walker, S. J. (1994) Modelling the growth, survival and death of microorganisms in foods: the UK Food Micromodel approach. Int. J.
Food Microbiol., 23, 265-275.

Miyake, T., Araki, S., and Tsuchido, T. (1993) Synthesis and sedimentation of a subset of $15 \mathrm{kD}$ heat shock proteins in Escherichia coli cells recovering from sublethal heat stress. Biosci. Biotechnol. Biochem., 57, 578-583.

Roberts, T. A. (1997) Microbial growth and survival: Developments in predictive modeling. Food Technol., 51, (4), 88-90.

Takano, M., and Tsuchido, T. (1982) Availability of growth delay analysis for the evaluation of total injury of stressed bacterial populations. J. Ferment. Technol., 60, 189-198.

Tsuchido, T. (1997) Examples of heat-injured microbes and measures against them (in Japanese). In Technology of Heat Sterilization (ed., Takano, M., and Tsuchido, T.), pp. 57-68, Science Forum, Tokyo.

Tsuchido, T. (1998) Building of database and future problems concerning heat sterilization (in Japanese). Bull. Jpn. Soc. Res. Food Prot., 4, 2-5.

Tsuchido, T., Takano, M., and Shibasaki, I. (1974) Effect of temperature-elevating process on the subsequent isothermal death of Escherichia coli K12. J. Ferment. Technol., 52, 788-792.

Tsuchido, T., Hayashi, M., Takano, M., and Shibasaki, I. (1982) Alteration of thermal resistance of microorganisms in a non-isothermal heating process. J. Antibacterial Antifungal Ag., Jpn., 10, 105-109.

Whiting, R. C. (1997) Microbial database building: What have we learned? Food Technol., 51, (4), 82-86.

Yano, N. (1998) Predictive microbiology and its application in food industry (in Japanese), Jpn. J. Food Microbiol., 15, 81-87. 